\title{
Increased harbor porpoise mortality in the Pacific Northwest, USA: understanding when higher levels may be normal
}

\author{
Jessica L. Huggins ${ }^{1, *}$, Stephen A. Raverty ${ }^{2}$, Stephanie A. Norman ${ }^{3}$, John Calambokidis ${ }^{1}$, \\ Joseph K. Gaydos ${ }^{4}$, Deborah A. Duffield ${ }^{5}$, Dyanna M. Lambourn ${ }^{6}$, James M. Rice ${ }^{7}$, \\ Brad Hanson ${ }^{8}$, Kristin Wilkinson ${ }^{9}$, Steven J. Jeffries ${ }^{6}$, Brent Norberg ${ }^{9}$, Lynne Barre ${ }^{9}$ \\ ${ }^{1}$ Collective, $218{ }^{1 / 2}$ W 4th Ave, Olympia, WA 98501, USA \\ ${ }^{2}$ British Columbia Ministry of Agriculture, Animal Health Centre, 1767 Angus Campbell Road, Abbotsford, \\ British Columbia V3G 2M3, Canada \\ ${ }^{3}$ Central Puget Sound Marine Mammal Stranding Network, Orca Network, 2403 North Bluff Road, Greenbank, WA 98253, USA, \\ and Marine-Med: Marine Research, Epidemiology, and Veterinary Medicine, 24225 15th Place SE, Bothell, WA 98021,USA \\ ${ }^{4}$ University of California Davis, UC Davis Wildlife Health Center-Orcas Island Office, 942 Deer Harbor Road, Eastsound, \\ WA 98245, USA \\ ${ }^{5}$ Portland State University, 1825 SW Broadway, Portland, OR 97207, USA \\ ${ }^{6}$ Washington Department of Fish and Wildlife, Marine Mammal Investigations, 7801 Phillips Rd SW Lakewood, WA 98498, USA \\ ${ }^{7}$ Oregon State University, Marine Mammal Institute, Hatfield Marine Science Center, Newport, OR 97365, USA \\ ${ }^{8}$ NOAA Fisheries, Northwest Fisheries Science Center, 2725 Montlake Boulevard East, Seattle, WA 98112, USA \\ ${ }^{9}$ NOAA Fisheries, Office of Protected Resources, 7600 Sand Point Way NE, Seattle, WA 98115, USA
}

\begin{abstract}
In 2006, a marked increase in harbor porpoise Phocoena phocoena strandings were reported in the Pacific Northwest of the USA, resulting in the declaration of an unusual mortality event (UME) for Washington and Oregon to facilitate investigation into potential causes. The UME was in place during all of 2006 and 2007, and a total of 114 porpoises stranded during this period. Responders examined 95 porpoises; of these, detailed necropsies were conducted on 75 animals. Here we review the findings related to this event and how these compared to the years immediately before and after the UME. Relatively equal numbers among sexes and age classes were represented, and mortalities were attributed to a variety of specific causes, most of which were categorized as trauma or infectious disease. Continued monitoring of strandings during 4 yr following the UME showed no decrease in occurrence. The lack of a single major cause of mortality or evidence of a significant change or event, combined with high levels of strandings over several postUME years, demonstrated that this was not an actual mortality event but was likely the result of a combination of factors, including: (1) a growing population of harbor porpoises; (2) expansion of harbor porpoises into previously sparsely populated areas in Washington's inland waters; and (3) a more well established stranding network that resulted in better reporting and response. This finding would not have been possible without the integrated response and investigation undertaken by the stranding network.
\end{abstract}

KEY WORDS: Phocoena phocoena $\cdot$ Stranding $\cdot$ Pacific Northwest · Unusual mortality event

\section{INTRODUCTION}

Harbor porpoises Phocoena phocoena are found year-round in inland and coastal waters in the Pacific Northwest of the USA (Calambokidis et al. 1987,
1997, Barlow 1988, Osborne et al. 1988, Green et al. 1992, Raum-Suryan \& Harvey 1998). In Washington and Oregon waters, 3 stocks are currently recognized: (1) Washington Inland Waters, (2) Northern Oregon/Washington Coast, and (3) Northern Califor- 
nia/Southern Oregon (Chivers et al. 2007, Carretta et al. 2014). The most recent abundance estimates from coastal surveys conducted in 2010 and 2011 by Forney et al. (2013) are 21487 harbor porpoises in the Northern Oregon/Washington Coast stock and 35769 in the Northern California/Southern Oregon stock. The Washington Inland Waters population was estimated at 10682 when last surveyed in 2002/2003 (Carretta et al. 2013). Although relatively abundant in regional waters, much of what is known about harbor porpoises in the Pacific Northwest comes from stranded animals, which represent only a small fraction of the true mortality even among nearshore species (Moore \& Read 2008, Williams et al. 2011).

Harbor porpoises are historically the most frequently stranded cetacean in the Northwest region of the USA (Norman et al. 2004a). Prior to 2006, the maximum annual number of harbor porpoise strandings recorded in Washington and Oregon was 34 in 2003 (Norman et al. 2004b, NOAA Fisheries unpubl. data). A dramatic increase in stranding frequency in 2006 compared to previous years prompted the declaration of an unusual mortality event (UME) by the National Marine Fisheries Service (NMFS) to facilitate the coordination of response and investigative efforts. The UME, declared in November 2006 and closed in July 2008, included all harbor porpoise strandings that occurred during 2006 and 2007 in Washington and Oregon. Here we provide the details and results of the multidisciplinary and collaborative investigation into this event, aimed at evaluating potential factors contributing to the increase in strandings (environmental, anthropogenic, and disease) and compare some of these to the years immediately surrounding the event.

\section{MATERIALS AND METHODS}

Because the official UME declaration was not made until well into the event (November 2006), the level of carcass examination for the majority of 2006 varied widely, depending on the experience of the responder, resources available, research goals and objectives, and carcass condition or location. At a minimum, Level A data, which include stranding date, species, location, carcass condition, age class, sex, length, weight, evidence of human interaction, and ultimate disposition of the carcass, were collected from all stranded animals (data used for this paper were current as of June 2012). Some of these values were estimated, particularly for cases in which a stranding was reported but there was no examination. After the UME was officially declared, a more concerted effort was made to quickly respond to all reported harbor porpoise strandings to recover carcasses for necropsy. Systematic gross necropsies were conducted on fresh animals whenever possible, and partial necropsies were conducted on carcasses that were moderately decomposed or moderately scavenged. Minimal samples (for genetics and life history) were collected from animals that were severely scavenged or in an advanced state of decomposition.

Sampling protocols differed slightly by stranding response group, but generally included frozen and histology samples of all major organs, with additional sampling of lesions observed on gross exam for ancillary studies. Frozen and formalin-fixed tissues collected for diagnostics were primarily submitted to the Animal Health Centre (British Columbia Ministry of Agriculture and Food) in Abbotsford, British Columbia, Canada, although a small number of Oregon cases $(n=3)$ were sent to the Oregon State University Veterinary Diagnostic Laboratory (Corvallis, Oregon). Stomachs were routinely collected intact for prey analysis at the National Marine Mammal Laboratory (Seattle, Washington) and Portland State University (Portland, Oregon). When available, feces and urine were sampled for biotoxin (domoic acid and saxitoxin) analysis at the NMFS biotoxin lab (Seattle, Washington). Algal toxins were quantified in extracts using the antibody-based enzyme-linked immunosorbent assay, as described by Lefebvre et al. (2010). Skin samples were submitted to Southwest Fisheries Science Center (La Jolla, California) to support ongoing genetic studies, and duplicate genetic samples were archived by the collecting organization. When appropriate or warranted by diagnostic findings, additional samples were sent from individual cases to the National Institutes of Health (Bethesda, Maryland), the Centers for Disease Control (Atlanta, Georgia), and the Washington Department of Agriculture (Olympia, Washington). Blubber, muscle, kidney, and liver samples were archived for future chemical contaminant analyses.

In addition to general histopathology, polymerase chain reaction (PCR) and bacteriology were conducted on collected tissues, and heavy metal, trace mineral, and vitamin A analyses were completed on liver samples. Pooled tissues (brain, lymph node, spleen, and lung) were screened by PCR for morbilliviruses and Brucella spp. (using primers in Krafft et al. 1995 and Bricker et al. 2000, respectively). In those cases with evidence of protozoal parasitism, characterized by either non-suppurative and occasion- 
ally necrotizing meningoencephalitis or parasitemia, follow-up immunohistochemistry of the brain for Toxoplasma gondii, Sarcocystis neurona, or Neospora caninum, and PCR of pooled tissues to screen for Apicomplexa, were undertaken using the methods described by Gibson et al. (2011). Bacterial cultures and antibiograms of Enterococcus spp. or Escherichia coli were regularly conducted on lung, spleen, lymph nodes, brain, small intestine, and colon. Ancillary cultures were undertaken as needed based on gross observations. Liver samples were analyzed for vitamin A, cadmium, calcium, copper, iron, lead, manganese, mercury, selenium, and zinc. In select cases, aspirated vitreous or aqueous humor was collected and submitted for blood urea nitrogen, calcium, and phosphorus level determination.

Spatio-temporal clustering tests were used to assess spatial and temporal patterns of strandings on global and local scales; results of these tests were reported by Norman et al. (2012). The SaTScan (version 7.0) analysis described by Norman et al. (2012) was re-run for this study with cause of death included, to test whether a cause of death was randomly distributed along the coastline or inland waters where harbor porpoise carcasses were recovered.

Age class was standardized by length into 3 categories (adult, subadult, and calf) using the ranges for known-age animals collected in Washington waters by Gearin et al. (1994). Primary and secondary causes of death (COD) were assigned according to the morphological diagnosis, severity, extent, and duration of the disease process. These data were provided by a veterinary pathologist, the gross examiner, or in consultation with both parties. Findings were resolved into 13 categories: (1) Accident/Trauma, with no evi- dence of human interaction; (2) Fishery Interaction, confirmed; (3) Fishery Interaction, suspected; (4) Infection/Inflammation; (5) Nutritional; (6) Congenital; (7) Euthanasia; (8) Metabolic; (9) Neoplastic; (10) Undetermined; (11) Live/released; (12) Not Examined; (13) Unknown.

\section{RESULTS}

In 2006, a total of 64 stranded harbor porpoises were reported throughout the region, a marked increase over previous years (1990-2005, mean = 15.8 strandings $\mathrm{yr}^{-1}, \mathrm{SD}=9.6$; Fig. 1). Another 50 harbor porpoises were reported and confirmed in 2007 , for a total of 114 strandings throughout the region during the 2 yr UME period (Figs. 1 \& 2). The increase did not appear to extend into the surrounding regions of British Columbia and northern California, which reported no significant changes in stranding occurrence in 2006 and 2007 (DFO Pacific Region Marine Mammal Response Program Database unpubl. data, J. Greenman pers. comm.).

The 114 harbor porpoise strandings during the UME included 7 live-stranded animals: 4 were immediately released by private citizens, 2 were euthanized by stranding network members, and 1 died during the stranding event, resulting in a total of 110 dead porpoises. Most of these were fresh dead (51\%, $\mathrm{n}=56)$ or moderately decomposed $(32 \% \mathrm{n}=35) ; 11 \%$ ( $\mathrm{n}=12$ ) were in an advanced state of decomposition, $5 \%(n=6)$ were mummified or skeleton only, and a single animal was of unknown condition (1\%). Of the 110 dead porpoises, 95 were examined by stranding responders: 14 (15\%) were external examinations
Fig. 1. Harbor porpoise Phocoena phocoena strandings in the US Pacific Northwest from 1990 to 2011, by year and region. OR: Oregon, WAIN: Washington inland waters, WAOC: Washington outer coast

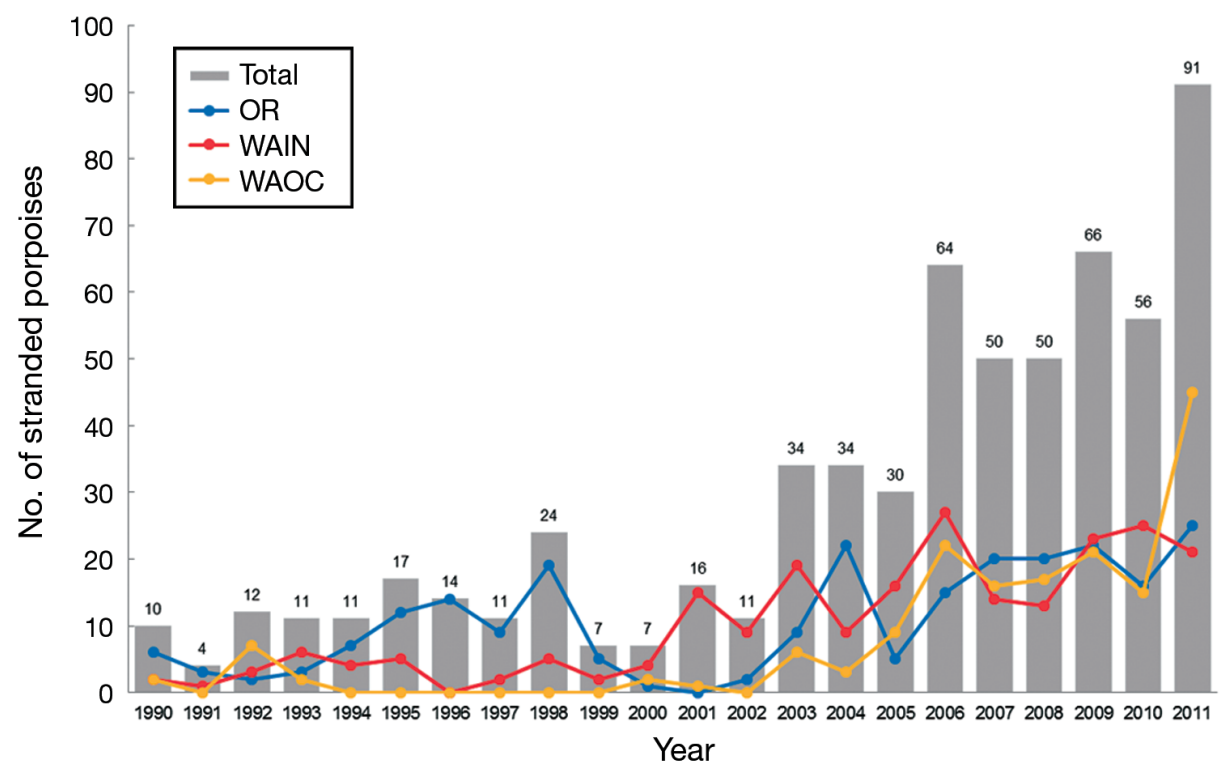




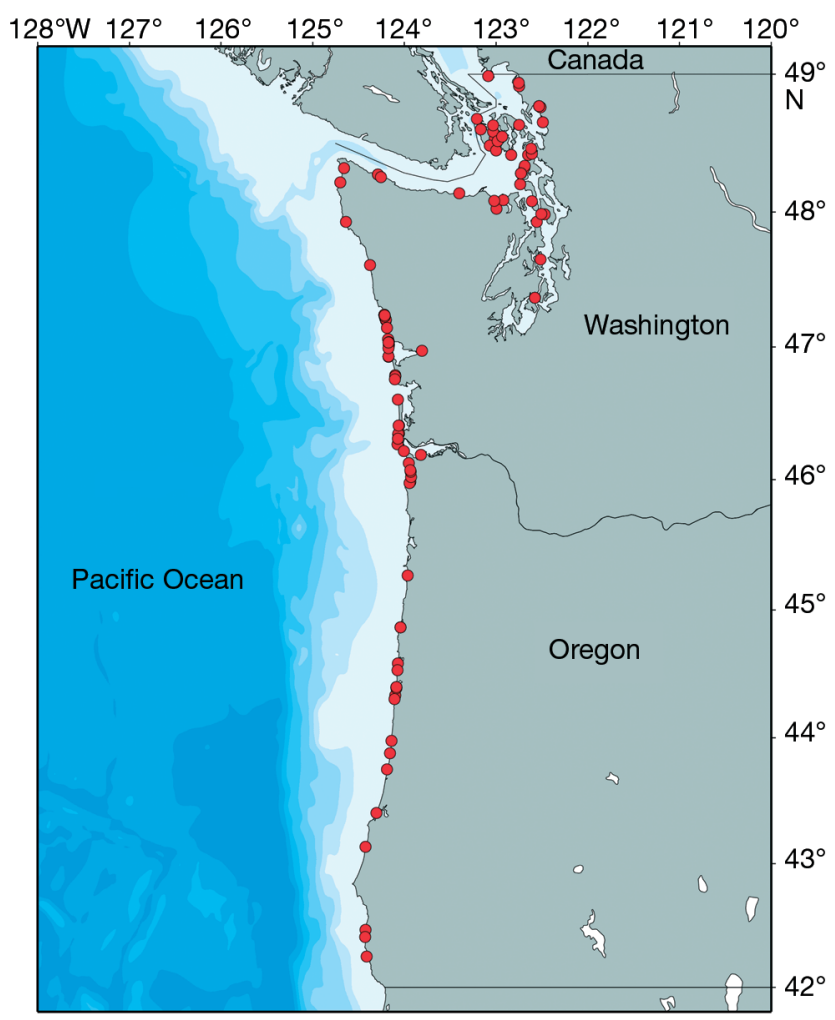

Fig. 2. Locations of stranded harbor porpoises Phocoena phocoena during the 2006-2007 unusual mortality event in the US Pacific Northwest

only, $6(6 \%)$ were external exams with minimal sampling, 17 (18\%) were partial internal exams of scavenged or decomposed carcasses with some samples collected, and $58(61 \%)$ were complete internal examinations with extensive sampling.

Harbor porpoise strandings occurred in all seasons and geographic subareas within the Northwest region and included animals of all age classes and both sexes. Strandings were comprised of 37 females $(32.5 \%), 48$ males $(42.1 \%)$, and 29 of unknown gender $(25.4 \%)$. All age classes were represented (Table $1)$, with 34 adults $(29.8 \%), 36$ subadults $(31.6 \%), 41$ calves $(36.0 \%)$, and 3 unknown $(2.6 \%)$. There was a

Table 1. Sex and age class of harbor porpoises Phocoena phocoena stranded during the 2006-2007 unusual mortality event in the US Pacific Northwest

\begin{tabular}{|lrrrr|}
\hline \multirow{2}{*}{ Age class } & \multicolumn{3}{c}{ Sex } & \multicolumn{2}{c|}{ Total } \\
\cline { 2 - 4 } & Female & Male & Unknown nn & \\
\hline Adult & 12 & 20 & 2 & 34 \\
Subadult & 8 & 12 & 16 & 36 \\
Calf/neonate & 17 & 16 & 8 & 41 \\
Unknown & & & 3 & 3 \\
Total & 37 & 48 & 29 & 114 \\
\hline
\end{tabular}

higher proportion of calves during the UME $(36 \%)$ compared to prior years $(24 \%)$, most of which occurred during the summer, but the difference was not significant $\left(\chi^{2}, p=0.634\right)$. Stranded porpoises were found throughout the year, but the majority of stranded animals $(51.8 \%, \mathrm{n}=59)$ were recovered during the summer months (June to August), followed by nearly equal numbers in the spring (March to May, $20.2 \%, \mathrm{n}=23$ ) and fall (September to November, $18.4 \%, \mathrm{n}=21$ ), and the fewest during the winter (December to February, 9.6\%, $\mathrm{n}=11$, Fig. 3). In the years prior to $\mathrm{UME}$, peak numbers of strandings occurred in both the spring and the summer, with fewer animals in the fall and winter (Norman et al. 2004a), but this seasonal difference between UME and preUME years was not significant $\left(\chi^{2}, p=0.108\right)$. The proportion of strandings were equally split among 3 main geographic regions (Washington inland waters, the Washington outer coast, and the Oregon coast) during the UME $(36.8 \%, \mathrm{n}=42 ; 33.3 \%, \mathrm{n}=38$; and $29.8 \%, \mathrm{n}=34$, respectively; Fig. 4). This is a highly significant change $\left(\chi^{2}, \mathrm{p}=0.000\right)$ over pre-UME years, during which the majority of animals stranded on the Oregon coast $(47 \%)$ and in Washington inland waters $(40 \%)$, and few strandings were recorded on the Washington outer coast (13\%).

\section{COD}

Harbor porpoise mortalities during the UME were attributed to a number of different primary and secondary causes (Table 2), although many cases (47 primary and 64 secondary) were classified as 'Undetermined' due to lack of significant findings or poor

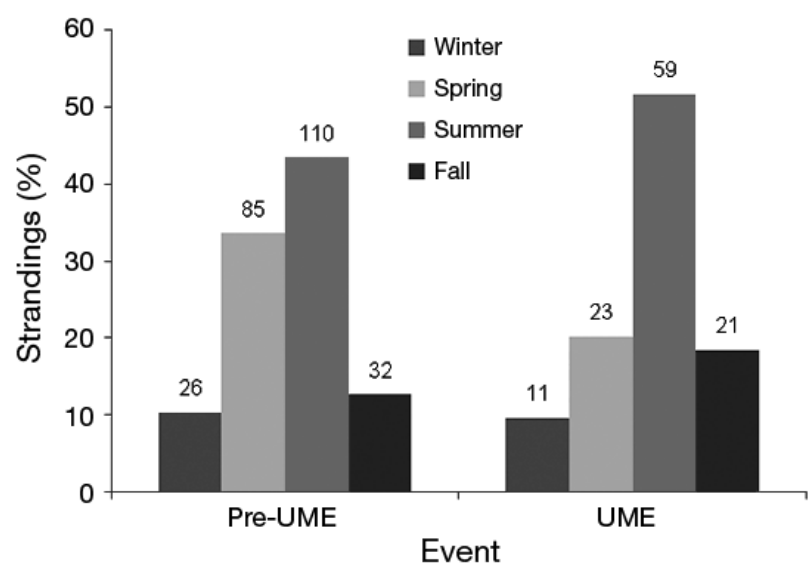

Fig. 3. Proportion of harbor porpoise Phocoena phocoena strandings by season, before the unusual mortality event (pre-UME:1990-2005) and during the UME (2006-2007). Actual numbers of strandings (n) are shown above bars 


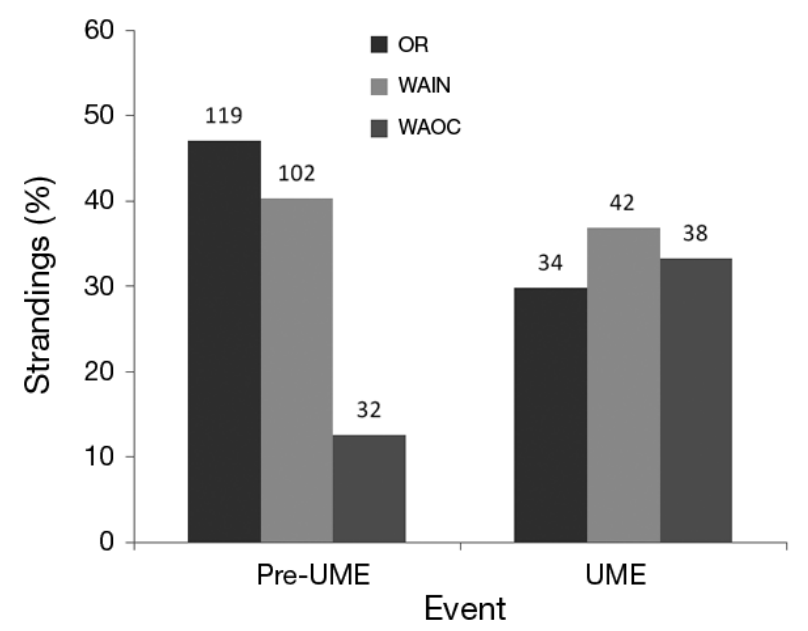

Fig. 4. Proportion of harbor porpoise Phocoena phocoena strandings by region, before the unusual mortality event (pre-UME:1990-2005) and during the UME (2006-2007). WAIN: Washington inland waters, WAOC: Washington outer coast, OR: Oregon. Actual numbers of strandings (n) are shown above bars

carcass condition (autolysis or scavenging). Of these, 38 had no major findings in either the primary or secondary COD, so were considered 'Undetermined' for both primary and secondary COD. There were secondary findings in 9 of the cases for which primary COD was 'Undetermined'; these findings would presumably have contributed in some degree to morbidity and possibly mortality of the animals. There were

Table 2. Frequency of primary and secondary causes of death in harbor porpoises Phocoena phocoena stranded during the unusual mortality event. COD: cause of death, HI: human interaction

\begin{tabular}{|c|c|c|c|}
\hline COD category & Primary COD & Secondary COD & Total \\
\hline Accident/trauma, non-HI & 15 & 5 & 20 \\
\hline Fishery interaction, confirmed & 7 & $2^{\mathrm{a}}$ & 7 \\
\hline Fishery interaction, suspected & & 3 & 3 \\
\hline Infection/inflammation & 19 & 14 & 33 \\
\hline Nutritional & 2 & 3 & 5 \\
\hline Congenital & 3 & 2 & 5 \\
\hline Metabolic & & 1 & 1 \\
\hline Neoplastic & & 1 & 1 \\
\hline Euthanized & 2 & & 2 \\
\hline Undetermined & 47 & 64 & $38^{\mathrm{b}}$ \\
\hline Live/released & 4 & 4 & 4 \\
\hline Not examined & 10 & 10 & 10 \\
\hline Unknown ${ }^{c}$ & 5 & 5 & 5 \\
\hline Total & 114 & 114 & \\
\hline \multirow{2}{*}{\multicolumn{4}{|c|}{$\begin{array}{l}\text { a The animals in these } 2 \text { cases also had fishery interaction as primary } \\
\text { COD, so they are omitted from the total number of cases for this category } \\
\text { b The total number of cases represents those for which both primary and } \\
\text { secondary COD were undetermined }\end{array}$}} \\
\hline & & & \\
\hline \multicolumn{4}{|c|}{$\begin{array}{l}\text { 'Stranding and necropsy reports could not be located for these individu- } \\
\text { als; they were therefore categorized as unknown }\end{array}$} \\
\hline
\end{tabular}

5 cases for which stranding and necropsy reports could not be located and were therefore categorized as unknown.

Of the 57 cases for which primary and/or secondary COD could be determined, infectious disease and trauma were the most commonly diagnosed conditions. Traumatic injuries were found in 30 animals ( $39 \%$ of primary COD and $14 \%$ of secondary COD); 20 of these did not have evidence of human interaction and included cases of asphyxiation on large fish, interspecific trauma, subcutaneous hemorrhage attributed to agonal death, and in neonates, dystocia. Fishery-related human interaction was confirmed as primary COD in 7 porpoises; 2 of these animals had fishery interaction as secondary COD as well. In both of these cases, the primary COD was due to trauma inflicted by the fishermen during the attempt to free the live animal from the net (gaff wounds and tailstock amputation). In 3 other cases, fishery interaction was suspected but could not be confirmed due to carcass condition. Mortality was attributed to infection/inflammation (localized infections or septicemia) in 33 cases $(33 \%$ of primary COD and $25 \%$ of secondary COD), 15 of which involved respiratory disease. Conditions in this category were attributed to a variety of pathogens (see below). There were 5 emaciated animals and in 2 of these cases, the absence of underlying pathology suggested a lack of available prey. There were 5 cases of presumptive dystocia, 2 porpoises that were euthanized, and individual cases of neoplasia and metabolic derangement (hypoglycemia).

\section{Infectious disease}

Several infectious disease agents were identified among the examined animals, with varying contributions to mortality. In 17 porpoises, PCR was positive for Apicomplexa, and followup gene sequencing and speciation was conducted at the National Institutes of Health (Gibson et al. 2011, Table 3). Protozoal infection was considered primary cause of death in 3 cases and a contributing factor in 5 others during the UME; significant protozoal lesions were most frequently found in the brain (meningoencephalitis) and heart (myocarditis) in these animals. Interestingly, 2 cases of Neospora spp. infection were also 
Table 3. Organisms found by PCR in harbor porpoises Phocoena phocoena stranded during the unusual mortality event, the tissues from which the organism was amplified, and the relation to cause of death (COD); NA: not assessed

\begin{tabular}{|c|c|c|c|}
\hline Field ID & Organism found & Relation to COD & Tissues affected \\
\hline 07-WC-001 & Sarcocystis & Contributing & Brain, lung \\
\hline CRC-733 & Neospora & Incidental & NA \\
\hline CRC-754 & Toxoplasma and Sarcocystis & Contributing & Heart, spinal cord, lymph node \\
\hline CRC-757 & Toxoplasma and Sarcocystis & Contributing & Brain, heart, lymph node \\
\hline CRC-767 & Toxoplasma and Sarcocystis & Incidental & Brain, heart, lymph node \\
\hline CRC-768 & Toxoplasma and Sarcocystis & Incidental & Heart, lung \\
\hline CRC-769 & Sarcocystis & Incidental & Brain, heart \\
\hline CRC-773 & Toxoplasma & Incidental & Lymph node \\
\hline CRC-774 & Toxoplasma & Incidental & Heart, eye \\
\hline CRC-777 & Toxoplasma and Sarcocystis & Immediate & Heart, lymph node \\
\hline CRC-787 & Toxoplasma and Sarcocystis & Immediate & Brain, heart, lymph node, mammary \\
\hline CRC-798 & Toxoplasma and Sarcocystis & Incidental & Brain, heart \\
\hline CRC-798 and CRC-798Fetus & Coxiella & Unknown & Placenta \\
\hline CRC-801 & Toxoplasma & Contributing & Heart \\
\hline WDFW0107-02 & Toxoplasma and Sarcocystis & Contributing & Brain, heart \\
\hline WDFW0407-04 & Toxoplasma and Sarcocystis & Immediate & Brain, heart, lymph node \\
\hline WDFW0607-04 & Toxoplasma & Incidental & Brain \\
\hline WDFW1207-04 & Neospora & Incidental & NA \\
\hline
\end{tabular}

detected; however, the lack of associated pathology with these 2 animals suggested either an incidental or asymptomatic infection. Coxiella burnetii was identified by PCR in a single pregnant porpoise (Kersh et al. 2012) with concurrent and incidental Toxoplasma gondii and Sarcocystis neurona infections. The relation of $C$. burnetii to the mortality of the individual could not be determined.

Respiratory illness was a common finding among examined animals and in 15 cases was severe enough to have contributed significantly to mortality. Most of these $(n=10)$ were related to common parasitic, bacterial, and viral infections. The fungus Cryptococcus gattii was recovered from 6 individuals, including a case of transplacental cryptococcosis (Norman et al. 2011). C. gattii emerged in the Pacific Northwest in 1999 on Vancouver Island, British Columbia, and by 2004 had spread to mainland British Columbia, affecting humans and terrestrial and aquatic animals (Stephen et al. 2002, Datta et al. 2009). The first case of C. gattii in harbor porpoises in Washington State occurred in 2002 (S. Raverty unpubl. data). During the UME, 4 of the 5 Cryptococcus-positive adults were female, and all 5 adults were recovered from Washington inland waters. Infections in all cases in which this fungus was detected were sufficiently severe to have caused the death of the animal.

No Brucella spp. or morbilliviruses were detected by PCR in any of the screened tissue samples $(\mathrm{n}=61)$; however, Brucella sp. was detected in 1 individual and suspected in another based on serology results (buffered plate antigen test and card test).
The frequencies of bacteria found in sampled tissues are presented in Table 4 . Not all tissues yielded microbial growth; decomposition, prolonged freezing, and overgrowth with Proteus spp. hampered recovery. Thirty-four bacterial isolates were recovered from 57 of 75 necropsied animals, with the most common being Escherichia coli, Edwardsiella tarda, Enterococcus spp., Pseudomonas putida, and Shewanella putrefaciens. Although most of the bacteria recovered are considered normal flora, post mortem invaders, or secondary opportunists, significant bacterial infections were found in 7 cases and involved the following isolates: E. coli, Pseudomonas fluorescens, Salmonella typhimurium, Staphylococcus aureus, Vibrio alginolyticus, V. cholerae, V. parahaemolyticus, and Yersina pseudotuberculosis.

\section{Toxicology}

Metal and trace mineral values were compared to established in-house reference limits (Table 5). Mean levels for stranded porpoises were within normal values for all analytes measured with the exception of selenium. Individual animal levels above normal ranges were detected in stranded porpoises for calcium, copper, mercury, manganese, selenium, and zinc; however, none were considered clinically significant. Individual levels that were detected below normal ranges included calcium, magnesium, and manganese. There was variation in derived vitamin A levels, which may reflect dietary deficiency associ- 
Table 4. Frequency of bacteria recovered from stranded harbor porpoises Phocoena phocoena during the unusual mortality event. Bold text indicates isolates that contributed to mortality in some individuals

\begin{tabular}{|lc|}
\hline Pathogen & No. infected animals \\
\hline Acinetobacter spp. & 1 \\
Aeromonas enchelaeia & 1 \\
Aeromonas enteropelogenes & 2 \\
Aeromonas hydrophila & 2 \\
Chryseobacterium sp. & 1 \\
Edwardseilla tarda & 7 \\
Enterococcus spp. & 6 \\
Escherichia coli & 5 \\
Escherichia coli (non-hemolytic) & 5 \\
Escherichia coli (toxigenic) & 2 \\
Gemella haemolysans & 2 \\
Hafnia alvei & 2 \\
Lactobacillus spp. & 1 \\
Paneoae spp. & 1 \\
Pantoea spp. & 3 \\
Pasteurella multocida & 2 \\
Proteus spp. & 1 \\
Pseudomonas fluorescens & $\mathbf{1}$ \\
Pseudomonas putida & 4 \\
Pseudomonas spp. & 1 \\
Pseudomonas fulva & 1 \\
Rahnella aquatilis & 1 \\
Salmonella typhimurium & 1 \\
Shewanella putrefaciens & $\mathbf{1}$ \\
Staphylococcus aureus & 4 \\
Staphylococcus sp. & $\mathbf{1}$ \\
Streptococcus sp. (non-hemolytic) & 1 \\
Streptococcus spp. & 1 \\
Streptococcus spp. (alpha hemolytic) & 3 \\
Vibrio alginolyticus & 1 \\
Vibrio cholerae & $\mathbf{2}$ \\
Vibrio parahaemolyticus & $\mathbf{1}$ \\
Vibrio proteolyticus & $\mathbf{1}$ \\
Vibrio sp. & 1 \\
Yersinia pseudotuberculosis & 3 \\
& 1 \\
\end{tabular}

ated with inappetence or emaciation, post mortem degradation, and other factors (Rolland 2000).

\section{Food habits and biotoxins}

Prey remains (or milk) were found in 17 of 41 examined stomachs. No unusual prey items were found, and contents did not reflect any change in food habits compared to previous studies (Gearin et al. 1994, Walker et al. 1998). Biotoxin (domoic acid and saxitoxin) test results were below detectable limits for all available urine and fecal samples ( $\mathrm{n}=16$ and 24, respectively).

\section{Spatial analysis}

SaTScan analysis, adjusting for cause of death, revealed a significant spatio-temporal cluster of 6 strandings in a $25 \mathrm{~km}$ area in the eastern end of the Strait of Juan de Fuca in northwestern Washington $\left(\mathrm{p}=0.0024\right.$, centered at $48.138^{\circ} \mathrm{N}, 123.403^{\circ} \mathrm{W}$, Fig. 5). Cause of death in $50 \%(n=3)$ of the stranded animals in this cluster indicated some degree of respiratory illness (verminous pneumonia, C. gattii infection, pneumonia due to $S$. aureus).

\section{Post-UME monitoring}

Mortalities in early 2008 appeared to have returned to levels more closely resembling years prior to the UME. However, in mid-2008, harbor porpoise

Table 5. Compiled values for metals, trace minerals, blood urea nitrogen (BUN), and vitamin A for harbor porpoises Phocoena phocoena stranded during an unusual mortality event (UME). Metals with means outside of the normal range are shown in bold. ND: not detectable, NA: not applicable. All values are ppm, except Vitamin A, which is $\mu \mathrm{g} \mathrm{g}^{-1}$

\begin{tabular}{|lccccc|}
\hline Element & Tissue & UME range & $\mathrm{n}$ & Mean & Normal range \\
\hline $\mathrm{Ca}$ & Liver & $48-562$ & 18 & 116.17 & $50-200$ \\
$\mathrm{Cd}$ & Liver & $0.2-1.5$ & 27 & 0.34 & $0.1-10.0$ \\
$\mathrm{Cu}$ & Liver & $7.2-129$ & 21 & 42.79 & $3-50$ \\
$\mathrm{Fe}$ & Liver & $104-272$ & 12 & 154.58 & $100-400$ \\
$\mathrm{Hg}$ & Liver & $0.1-341$ & 29 & 18.51 & $0.1-30.0$ \\
$\mathrm{Mg}$ & Liver & $18.5-509$ & 23 & 208.15 & $100-250$ \\
$\mathrm{Mn}$ & Liver & $0.5-7.7$ & 18 & 3.43 & $2.0-6.0$ \\
$\mathrm{~Pb}$ & Liver & ND to $<2.0$ & 22 & $\mathbf{8 . 4 9}$ & $\mathbf{0 . 3 0 - 2 0 . 0}$ \\
$\mathrm{Se}$ & Liver & $\mathbf{0 . 4 6 - 9 1 . 2}$ & $\mathbf{3 4}$ & 54.68 & $20-120$ \\
$\mathrm{Zn}$ & Liver & $25-142$ & 19 & 250.39 & 66.59 \\
$\mathrm{BUN}$ & Vitreous humor & $27.2-951$ & 13 & 100.03 & 1206.69 \\
$\mathrm{Ca}$ & Vitreous humor & $8.9-218$ & 12 & $200-3500$ \\
$\mathrm{P}$ & Vitreous humor & $1.7-440$ & $0.2-10877$ & 26 & 2 \\
\hline
\end{tabular}




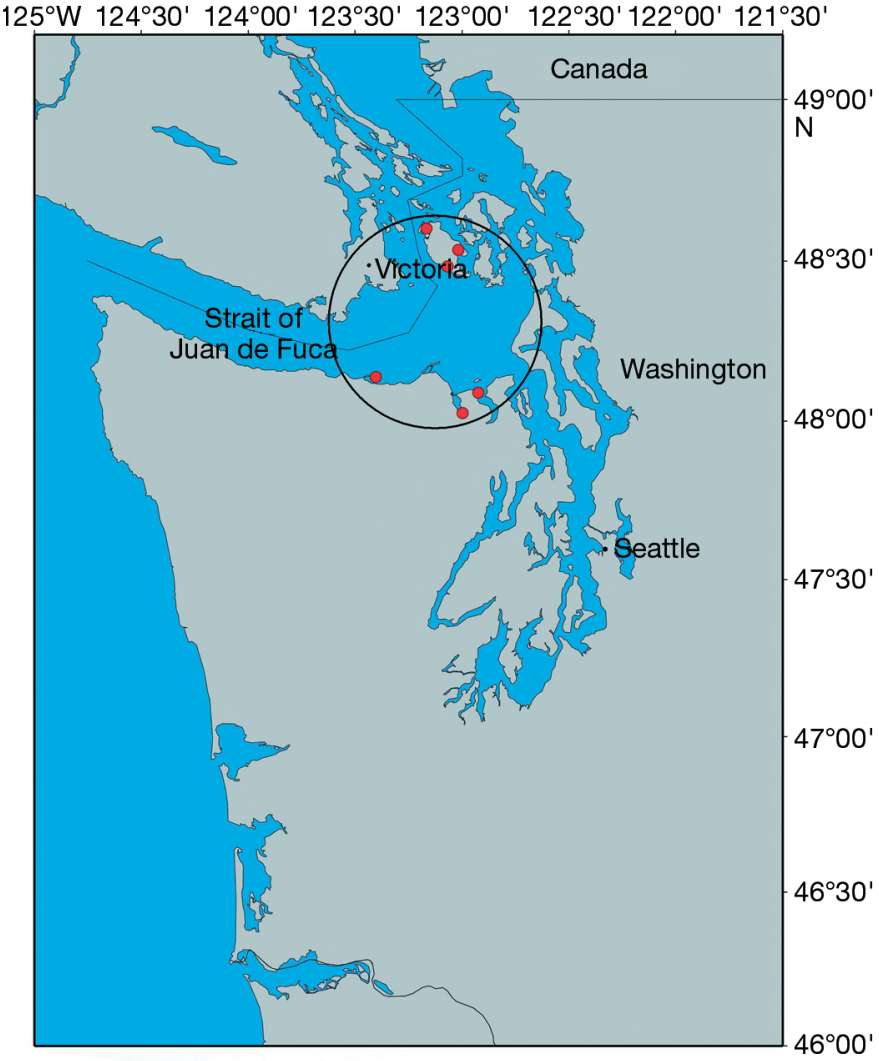

Fig. 5. Significant spatio-temporal cluster of harbor porpoise Phocoena phocoena strandings in the eastern end of the Strait of Juan de Fuca identified by SaTScan analysis with primary cause of death included. Respiratory disease was involved in $50 \%$ of these cases

strandings increased again, and by the end of the year, the total number of strandings was equal to that of 2007 ( $n=50)$. Continued monitoring of, and response to, reported porpoise strandings over the following $4 \mathrm{yr}$ showed an increase in stranding occurrence after the UME, with 66 strandings in 2009, 56 in 2010, and 91 in 2011 (Fig. 1). Stranding patterns and causes of death during the post-UME period were found to be similar to those that occurred during the UME. Where COD could be determined $(\mathrm{n}=$ 91), traumatic injuries (various etiologies) and infectious disease (multiple sources) each accounted for $43 \%$ of the mortalities in post-UME porpoises.

\section{DISCUSSION}

The UME appears to stem from broader factors than a single disease outbreak or localized incident because there was no single or combination of pathologic findings that accounted for the increased strandings, despite the relatively large proportion of animals with undetermined primary and secondary diagnoses. This finding was supported by the lack of local clustering in the spatial analysis, which suggests that the strandings were the result of more varied etiologies instead of localized causes (Norman et al. 2012). Causes of mortality in this case series are similar to those documented with ongoing passive surveillance of animals recovered within the Pacific Northwest (S. Raverty unpubl. data) and those that were identified in a subset of animals collected and examined as part of the 2003 USS 'Shoup' midfrequency sonar investigation (Norman et al. 2004b). Cause of death could only be determined for 5 of 11 porpoises examined as part of that investigation; 2 were attributed to traumatic injury and the remaining 3 were the result of infectious disease processes (salmonellosis, pneumonia, and peritonitis). Although a large number of animals had primary or secondary diagnoses of infection or inflammation during the UME (nearly half of these due to respiratory illnesses), this proportion would be anticipated with wild stranded individuals and has been observed in stranded porpoises in other regions (Baker \& Martin 1992, Siebert et al. 2001, Jauniaux et al. 2002, Bogomolni et al. 2010, Wright et al. 2013). The spatio-temporal cluster of mortality involving respiratory disease in the eastern end of the Strait of Juan de Fuca is interesting and may have been a consequence of local factors, such as increased exposure to respiratory diseases or increased harbor porpoise susceptibility in this particular area. The findings of Cryptococcus gatti and protozoal infections in harbor porpoises are of interest, but due to the relatively small proportion of individual animals affected, they are not considered significant contributors to the UME. Additionally, the elevated number of harbor porpoise strandings documented during and after the UME is unlikely to be related to shifts in ocean temperatures, as these strandings occurred during both warm and cool ocean phases which were reflected in the sea surface temperatures analyzed from a NOAA weather buoy off Newport, Oregon, by Peterson et al. (2012).

The increase in observed mortalities documented during the UME and post-UME periods is likely the result of a combination of increased reporting/investigation of strandings and increased abundance of harbor porpoises, although the degree to which these factors played a role vary by region. Increased reporting associated with heightened response effort and public awareness beginning in the early 2000 s (supported by funding from the John $\mathrm{H}$. Prescott 
Marine Mammal Rescue Assistance Grant Program) was an important factor on the Washington outer coast, where many areas are remote and thus subject to underreporting (Norman et al. 2004a). Once the UME was declared, additional efforts were made to encourage reporting and to investigate harbor porpoise strandings, which continued after the closure of the UME. In contrast, increased reporting is less likely to have been as important in Washington inland waters, where highly populated coastlines and more visible stranding response organizations have resulted in more consistent detection and reporting of carcasses (Norman et al. 2004b). While harbor porpoise populations appear to have increased throughout our study region, the most dramatic increase has occurred in the inland waters of Washington State (Strait of Juan de Fuca and San Juan Islands), where harbor porpoise abundance is estimated to have grown from 3506 in 1996 to 10682 in 2002-2003 (Carretta et al. 2013 based on Calambokidis et al. 1997, Laake et al. 1997). More recent abundance data are not currently available for this region, but this trend appears to have continued and extended into the greater Puget Sound area (Cascadia Research unpubl. data), where harbor porpoises were once abundant (Scheffer \& Slipp 1948) but had essentially vanished by the 1970s (Everitt et al. 1979, Osborne et al. 1988). Abundance off the OregonWashington coasts does not appear to have undergone a dramatic change. Although there were some minor variations in survey methods and areas, 3 survey periods from 1997 to 2011 all yielded abundance estimates in the range 15000-22 000 for the northern Oregon-Washington stock (Laake et al. 1998, Forney et al. 2013, Carretta et al. 2014). If this population has been near carrying capacity, it could have contributed to the dramatic increase observed in inland waters.

We conclude the harbor porpoise UME and continued increased numbers of strandings are due to changes in the harbor porpoise population coupled with improved reporting, and not the result of a major mortality event. This is supported by evidence that harbor porpoise strandings are continuing at rates similar to, or higher than, those recorded during the UME. No clear spatial and temporal pattern, nor common postmortem trends were observed for the UME. The higher levels of harbor porpoise strandings that prompted the declaration of the UME appear to be, in fact, normal. This conclusion was made possible by the multidisciplinary investigative efforts of the stranding network both during and after the event closure.
Acknowledgements. Many Northwest Marine Mammal Stranding Network participants facilitated the response, recovery, and examination of stranded porpoises; we particularly thank Amy Traxler of the Whale Museum and the volunteers of the San Juan County Marine Mammal Stranding Network; Susan Berta, Sandy Dubpernell, and Matt Klope of Central Puget Sound Marine Mammal Stranding Network; staff and volunteers of Washington Department of Fish and Wildlife; Washington State Parks; and Keith Chandler of Seaside Aquarium for their response assistance. We also thank Nelio Barros for examining porpoises from northern Oregon and southern Washington. Rob Bildfell of Oregon State University processed the Oregon cases sent to the Veterinary Diagnostic Laboratory and provided valuable feedback on other case material. Food habit analysis was undertaken by William Walker of the National Marine Mammal Laboratory. Genotyping of Toxoplasma gondii and Sarcocystis neurona was performed by Dr. Mike Griggs of the National Institutes of Health. Funding for stranding response and tissue analysis was provided by the John H. Prescott Marine Mammal Rescue Assistance Grant Program and the Marine Mammal Unusual Mortality Event Fund.

\section{LITERATURE CITED}

Baker JR, Martin AR (1992) Causes of mortality and parasites and incidental lesions in harbour porpoises (Phocoena phocoena) from British waters. Vet Rec 130: $554-558$

Barlow J (1988) Harbor porpoise, Phocoena phocoena, abundance estimation for California, Oregon, and Washington: I. Ship surveys. Fish Bull 86:417-432

Bogomolni AL, Pugliares KR, Sharp SM, Patchett K and others (2010) Mortality trends of stranded marine mammals on Cape Cod and southeastern Massachusetts, USA, 2000 to 2006. Dis Aquat Org 88:143-155

Bricker B, Ewalt DR, MacMillan AP, Foster G, Brew S (2000) Molecular characterization of Brucella strains isolated from marine mammals. J Clin Microbiol 38:1258-1262

Calambokidis J, Steiger GH, Cubbage JC (1987) Marine mammals in the southwestern Strait of Juan de Fuca: natural history and potential impacts of harbor development in Neah Bay. Contract No. DACW67-85-M-0046. Final report prepared by Cascadia Research Collective, Olympia, WA, for the Seattle District, Army Corps of Engineers, Seattle, WA

Calambokidis J, Osmek S, Laake JL (1997) Aerial surveys for marine mammals in Washington and British Columbia inside waters. Final report prepared by Cascadia Research Collective, Olympia, WA for the National Marine Mammal Laboratory, Seattle, WA

Carretta JV, Oleson E, Weller DW, Lang AR and others (2013) U.S. Pacific marine mammal stock assessments: 2012. Tech Memo NMFS-SWFSC-504. US Department of Commerce, NOAA, La Jolla, CA

Carretta JV, Oleson E, Weller DW, Lang AR and others (2014) U.S. Pacific marine mammal stock assessments (DRAFT): 2013. Tech Memo NMFS-SWFSC-532. US Department of Commerce, NOAA, La Jolla, CA

Chivers SJ, Hanson B, Laake J, Gearin P and others (2007) Additional genetic evidence for population structure of Phocoena phocoena off the coasts of California, Oregon, and Washington. Administrative Report LJ-07-08. Southwest Fisheries Science Center, La Jolla, CA 
Datta K, Bartlett KH, Baer R, Byrnes E and others (2009) Spread of Cryptococcus gattii into Pacific Northwest Region of the United States. Emerg Infect Dis 15: 1185-1191

Everitt RD, Fiscus CH, DeLong RL (1979) Marine mammals of northern Puget Sound and the Straits of Juan de Fuca: a report on investigations November 1, 1977-October 31, 1978. Final report to the Marine Mammal Division, Northwest and Alaska Fisheries Center, NMFS, Seattle, WA. Tech Memo ERL MESA-41. US Department of Commerce, NOAA, Seattle, WA

Forney KA, Carretta JV, Benson SR (2013) Preliminary estimates of harbor porpoise abundance in Pacific Coast waters of California, Oregon and Washington, 2007-2012. Draft Document PSRG-2013-10 submitted to the Pacific Scientific Review Group, 2-4 April 2013, San Diego, CA

Gearin PJ, Melin SR, DeLong RL, Kajimura H, Johnson MA (1994) Harbor porpoise interactions with a chinook salmon set-net fishery in Washington State. Rep Int Whaling Comm (Spec Issue) 15:427-438

Gibson AK, Raverty S, Lambourn DM, Huggins J, Magargal SL, Magargal L, Grigg ME (2011) Polyparasitism is associated with increased disease severity in Toxoplasma gondii-infected marine sentinel species. PLoS Negl Trop Dis 5:e1142

Green GA, Brueggeman JJ, Grotefendt RA, Bowlby CE, Bonnel ML, Balcomb KC III (1992) Cetacean distribution and abundance off Oregon and Washington, 1989-1990. In: Brueggeman JJ (ed) Oregon and Washington marine mammal and seabird surveys. Final Report, OCS Study MMS 91-0093, Minerals Management Service, US Dept. of Interior, Los Angeles, CA, p 1-100

Jauniaux T, Petitjean D, Brenez C, Borrens $M$ and others (2002) Post-mortem findings and causes of death of harbor porpoises (Phocoena phocoena) stranded from 1990 to 2000 along the coastlines of Belgium and Northern France. J Comp Pathol 126:243-253

> Kersh GJ, Lambourn DM, Raverty SA, Fitzpatrick KA and others (2012) Coxiella burnetii infection of marine mammals in the Pacific Northwest, 1997-2010. J Wildl Dis 48: 201-206

Krafft A, Lichy JH, Lipscomb TP, Klaunberg BA, Kennedy S, Taubenberger JK (1995) Postmortem diagnosis of morbillivirus infection in bottlenose dolphins (Tursiops truncatus) in the Atlantic and Gulf of Mexico epizootics by polymerase chain reaction-based assay. J Wildl Dis 31 410-415

Laake JL, Calambokidis J, Osmek SD, Rugh DJ (1997) Probability of detecting harbor porpoise from aerial surveys: estimating $g(0)$. J Wildl Manag 61:63-75

Laake JL, Calambokidis J, Osmek S (1998) Survey report for the 1997 aerial surveys for harbor porpoise and other marine mammals of Oregon, Washington and British Columbia outside waters. AFSC Processed Report 98-10. Marine Mammal Protection Act and Endangered Species Act Implementation Program 1997, p 77-97

Lefebvre KA, Robertson A, Frame ER, Colegrove KM and others (2010) Clinical signs and histopathology associated with domoic acid poisoning in northern fur seals (Callorhinus ursinus) and comparison of toxin detection methods. Harmful Algae 9:374-383
Moore JE, Read AJ (2008) A Bayesian uncertainty analysis of cetacean demography and bycatch mortality using age-at-death data. Ecol Appl 18:1914-1931

Norman SA, Bowlby CE, Brancato MS, Calambokidis J and others (2004a) Cetacean strandings in Oregon and Washington between 1930 and 2002. J Cetacean Res Manag 6:87-99

Norman SA, Raverty S, McLellan B, Pabst A and others (2004b) Multidisciplinary investigation of stranded harbor porpoises (Phocoena phocoena) in Washington State with an assessment of acoustic trauma as a contributory factor (2 May-2 June 2003). Tech Memo NMFS-NWR34. US Department of Commerce, NOAA. Seattle, WA

Norman SA, Raverty S, Zabek E, Etheridge S, Ford JKB, Hoang LMN, Morshed M (2011) Maternal-fetal transmission of Cryptococcus gattii in harbor porpoise. Emerg Infect Dis 17:304-305

Norman SA, Huggins J, Carpenter TE, Case JT and others (2012) The application of GIS and spatiotemporal analyses to investigations of unusual marine mammal strandings and mortality events. Mar Mamm Sci 28: E251-E266

Osborne R, Calambokidis J, Dorsey EM (1988) A guide to marine mammals of Greater Puget Sound. Island Publishers, Anacortes, WA

Peterson WT, Morgan CA, Peterson JO, Fisher JL, Burke BJ, Fresh K (2012) Ocean ecosystem indicators of salmon marine survival in the northern California current. 2011 NOAA Annual Report. Available at www.nwfsc.noaa. gov/research/divisions/fe/estuarine/oeip/documents/ peterson_etal_2011.pdf (accessed 12 May 2012)

Raum-Suryan KL, Harvey JT (1998) Distribution and abundance of and habitat use by harbor porpoise, Phocoena phocoena, off the northern San Juan Islands, Washington. Fish Bull 96:808-822

Rolland R (2000) A review of chemically-induced alterations in thyroid and vitamin A status from field studies of wildlife and fish. J Wildl Dis 36:615-635

Scheffer VB, Slipp JW (1948) The whales and dolphins of Washington State with a key to the cetaceans of the west coast of North America. Am Midl Nat 39:257-337

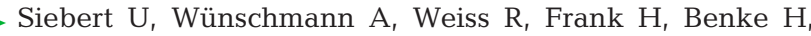
Frese K (2001) Post-mortem findings in harbour porpoises (Phocoena phocoena) from the German North and Baltic Seas. J Comp Pathol 124:102-114

Stephen C, Lester S, Black W, Fyfe M, Raverty S (2002) Multispecies outbreak of cryptococcosis on southern Vancouver Island, British Columbia. Can Vet J 43:792-794

Walker WA, Hanson MB, Baird RW, Guenther TJ (1998) Food habits of the harbor porpoise, Phocoena phocoena, and Dall's porpoise, Phocoenoides dalli, in the inland waters of British Columbia and Washington. AFSC Processed Report 98-10. Marine Mammal Protection Act and Endangered Species Act Implementation Program 1997, p 63-75

Williams R, Gero S, Bejder L, Calambokidis J and others (2011) Underestimating the damage: interpreting cetacean carcass recoveries in the context of the Deepwater Horizon/BP incident. Conserv Lett 4:228-233

- Wright AJ, Maar M, Mohn C, Nabe-Nielsen J and others (2013) Possible causes of a harbour porpoise mass stranding in Danish waters in 2005. PLoS ONE 8(2):e55553 